\title{
世羅地区に突発したナシ花腐細菌病の発生実態と着果, 奇形果及び果実肥大に及ぼす影響
}

\author{
坂本隆行・向谷裕次・新田浩通*・水主川桂宮** \\ （尾三地域事務所農林局地域営農課， *広島県立農業技術センター, \\ 現: 広島県農業改良普及センター, **広島県立農業技術センター果樹研究所）
}

広島県世羅地区のナシ開発団地では，2003年 4 月下旬 にナシの開花期に花腐症状が突発した。本症状は花弁, がく, 子房，果軸等が黒変し腐敗していたことや，黒変 組織からナシの幼果に病原性を持つPseudomonas 属菌 が分離されたこと等からナシ花腐細菌病（病原菌： Pseudomonas syringae pv. syringae van Hall 1902) である と診断した。

本病は, 1972年に大分県と福岡県で露地栽培の “二十 世紀’ , ‘新世紀’, ‘マメナシ’などに発病した2)ことや, 1997年に佐賀県で施設栽培の ‘幸水’に発病した1) こと が報告されているが，本邦における発病報告は極めて少 なく，本県では今回が初発生である。

このため, 本県における発生実態や発病を助長した要 因, 発病後における実用上の被害の有無について調査し, 若干の知見を得たので報告する。

\section{試 験 方 法}

ナシ花腐細菌病の発病率は, 2003年 4 月26日に初発生 を確認した後, 5 月 2 日に広島県世羅郡世羅町における 4 つのナシ生産団地を対象として，1生産団地につき 3 園地， 1 園地につき 5 樹， 1 樹につき $130 〜 750$ 花， 170 ～460葉を調査した。なお，“幸水”については12園全て を, “豊水”についてはA 生産団地の No. 1 園のみを調 査対象とした。

世羅地区における2003年及び平年の 4 月 10 日から 5 月 5 日までの間の最低気温及び降水量の気象観測データ は, 気象庁ホームページょり入手し, 花腐細菌病の発生 と気象要因との関連を解析した。

本病が着果, 奇形果, 果実肥大に及ぼす影響の調査は, A 生産団地の No. 1 園において下記の通りに行った。

本病の被害程度は，5月 2 日に，花そうに打溌生
程度を甚（花弁，がく，子房に被害有り）, 中（花弁， がくに被害有り), 軽（花弁のみに被害有り）及び無 (外観健全) の 4 段階に区分し, 多発生枝では, 甚 : 中 : 軽: 無の割合が $1: 3: 5: 1$, 少発生枝では, 甚: 中 : 軽 : 無の割合が $0: 1: 5: 4$ に近い值となるような側枝 を 8 樹から各 $2 \sim 3$ 枝, 計 20 枝/区を選定した。着果率 は，前記の基準により選定した結果母枝の着果数を 5 月 2 日に調査し， 5 月 14 日時点での樹上の残存果数を基に 算出した。奇形果率は, 前記の基準により選定した結果 母枝の着果数を 5 月 2 日に調査した後, 5 月 14 日に 1 花 そうにつき 1 果を残す割合で 1 次摘果を行い, 1 次摘果 時における奇形果数を求めて算出した。果実の肥大調査 は, 前記の基準により選定した結果母枝に着生した果実 を対象とし，5月14日，28日，6月26日（2 次摘果日） 及び 9 月 1 日に果実の横径を測定した。なお， 2 次摘果 基準は, 多発生枝並びに少発生枝ともに枝長 $20 \mathrm{~cm}$ につ き1果の割合とした。

\section{結果および考察}

世羅地区で露地栽培を行っている12のナシ園における “幸水” の発病花率（園地平均）は, 1.5〜 16.4\%であっ た。なお, 樹によっては, 発病花率が40.8\%を示した樹 もあった（第 1 表）。

また，花弁への発病が確認された樹では，葉の組織の 一部に黒変症状が認められた。この割合は，0.1〜 1. $0 \%$ であり, 花に比べて顕著に低い值であるが, 井手ら ${ }^{1)} や$ 佐藤ら ${ }^{2)}$ の報告には本病が葉に病徵を呈すことは記載さ れていない。葉の黒変症状発現部位からの菌の分離は, 今回未実施である。葉の症状が本病によるものであるか 否かについては，今後明らかにする必要がある。

ナシ花腐細菌病の発生については, 佐藤ら22) は1972年

Takayuki Sakamoto, Yuji Mukohdani, Hiromichi Nitta* and Katsura Kakogawa** (Reg. Agr. Aff. Div., Agr. For. Ber., Bisan. Reg. Off., *Hiroshima Pref. Agr. Res. Ctr., **Fruit Tree Res. Inst., Hiroshima Pref. Agr. Res. Ctr.): Occurrence of bacterial blossom blight and canker and effect to bearing, malformed fruit and fruit growth in Japanese pear orchards at Sera 2005年 2 月 3 日受理 
第 1 表 世羅地区におけるナシ花腐細菌病の発生実態

\begin{tabular}{|c|c|c|c|c|}
\hline 生産団地名 & $\begin{array}{l}\text { 園地 } \\
\text { No. }\end{array}$ & 品種名 & $\begin{array}{c}\text { 発病花率 } \\
(\%)\end{array}$ & $\begin{array}{c}\text { 黒変葉率 } \\
(\%)\end{array}$ \\
\hline \multirow[t]{4}{*}{ A 団地 } & 1 & 豊水 & $6.5(15.0)$ & 0.2 \\
\hline & 1 & 幸水 & $16.4(40.8)$ & 1.0 \\
\hline & 2 & 幸水 & 8. $3(13.1)$ & 0.5 \\
\hline & 3 & 幸水 & 4. $0 \quad(7.7)$ & 0.3 \\
\hline \multirow[t]{3}{*}{ B 団地 } & 1 & 幸水 & 4. $3 \quad(9.8)$ & 0.3 \\
\hline & 2 & 幸水 & $2.5 \quad(3.7)$ & 0.3 \\
\hline & 3 & 幸水 & $4.1 \quad(9.6)$ & 0.1 \\
\hline \multirow[t]{3}{*}{ C 団地 } & 1 & 幸水 & $3.4 \quad(5.5)$ & 0.3 \\
\hline & 2 & 幸水 & 4. $4 \quad(5.9)$ & 0.2 \\
\hline & 3 & 幸水 & $1.5 \quad(2.1)$ & 0.2 \\
\hline \multirow[t]{3}{*}{ D 団地 } & 1 & 幸水 & $4.3 \quad(6.2)$ & 0.2 \\
\hline & 2 & 幸水 & $10.4(13.7)$ & 1.0 \\
\hline & 3 & 幸水 & $4.2 \quad(5.7)$ & 0.2 \\
\hline
\end{tabular}

発病花率 : 左の值は, 園地平均。（ ）内の值は, 各園の最高 值。

に露地栽培で発生が確認された際に，4月初旬の異常低 温による霜害に伴って生じたことを報告している。また, 井手ら ${ }^{1)} は ， 1997$ 年に施設加温栽培で発生が確認された 際に，当作型では露地栽培に比べ樹勢が低下している樹 が多いことや，施設内が多湿になりやすいこと等が本病 の激発を招く原因であると報告している。

ナシ花腐細菌病が発生した世羅地区では, 開花前の 2003 年 4 月 10 日及び 16 日にそれぞれ $1.5^{\circ} \mathrm{C}$ 及び $2.8^{\circ} \mathrm{C}$ の 低温が認められ，“幸水”の開花始期にあたる 4 月 22 日 にも $1.7^{\circ} \mathrm{C}$ の低温が観測されているが，霜害は認められ ていない。また，その後の開花期間中にも霜害が発生す るほどの低温は認められていない。

一方，花蕾肥大期の 4 月 19 20日と開花期間中の 4 月
23〜26日にかけて降雨が連続しており，このうち，4月 19〜20日と 4 月 $24 \sim 25$ 日の平均気温は $15^{\circ} \mathrm{C}$ 以上の值を 示している (第 1 図)。また, 本病菌と同種のキウイフ ルーツかいよう病菌 (Pseudomonas syringae pv. actinidiae Takikawa, Serizawa, Ichikawa, Tsuyumi \& Goto 1989) は, $15 \sim 25^{\circ} \mathrm{C}$ で最も増殖し， $15^{\circ} \mathrm{C}$ で病斑の拡大が最も激し いことが報告されている3)。

これらのことから，2003年の世羅地区におけるナシ花 腐細菌病の発生には, 開花前から開花期にかけての霜害 は関与していないものの, 開花期間中の 4 月19〜20日と 4 月23〜26日にかけての連続降雨と降雨期間中における $15^{\circ} \mathrm{C}$ を超える気温の推移が大きく影響し, 本病の発生 を助長したものと推察された。

A 生産団地の No. 1 園において, “幸水” と “豊水” の発病花率を比較した結果, 発病花率は, “幸水”では $16.4 \%$ ，“豊水’では6.5\%であり，“幸水’は“豊水” に比べて多発生であった（第 1 表）。

しかし，当園における開花始期と満開期は，“幸水” では 4 月21日と 4 月 25 日，“豊水”では 4 月19日と 4 月 23日であり, “豊水”は ‘幸水”より $2 \sim 3$ 日早く開花 が推移していることから, この生育推移の差が発病花率 の差を生じた要因となった可能性がある。このため, 両 品種の本病に対する罹病性については，今後，接種試験 を含めて, さらに検討する必要がある。

本病の発病花率（園地平均）が16.4\%であり, 調査し た12園中で最も高かった A 生産団地の No. 1 園におい て，少発枝と多発枝における着果率と奇形果率を調査し た。

この結果, 着果率は, 少発枝では65.7\%であったのに 対し，多発枝では $42.8 \%$ でった（第 2 図）。また，奇

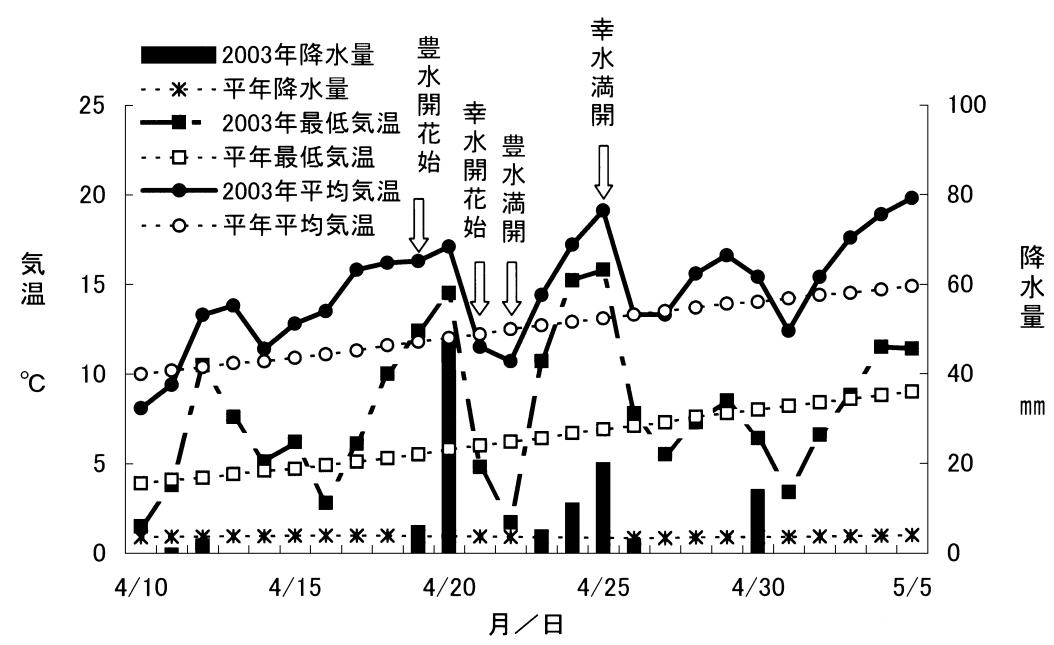

第 1 図 世羅地区における2003年 4 月 10 日〜 5 月 5 日の降水量と気温 

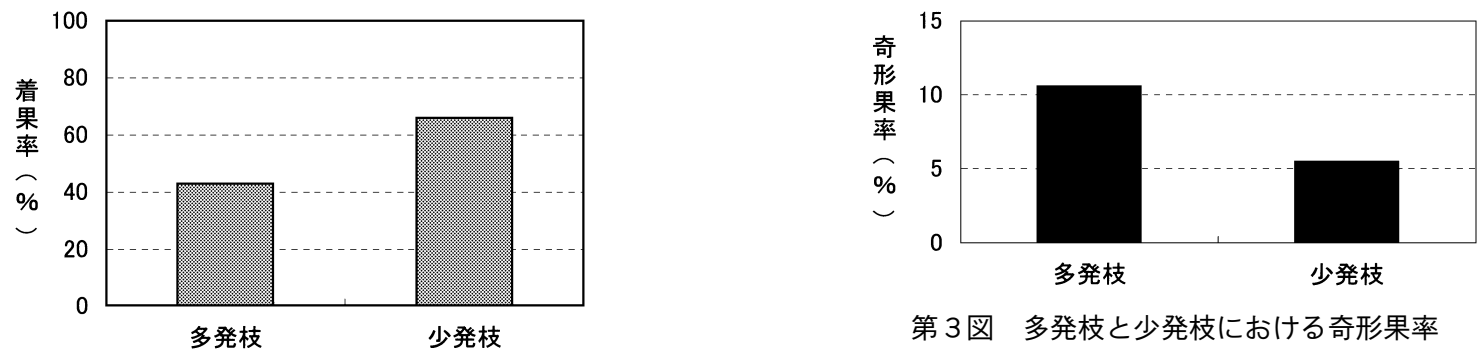

第3図多発枝と少発枝における奇形果率

第 2 図多発枝と少発枝における着果率

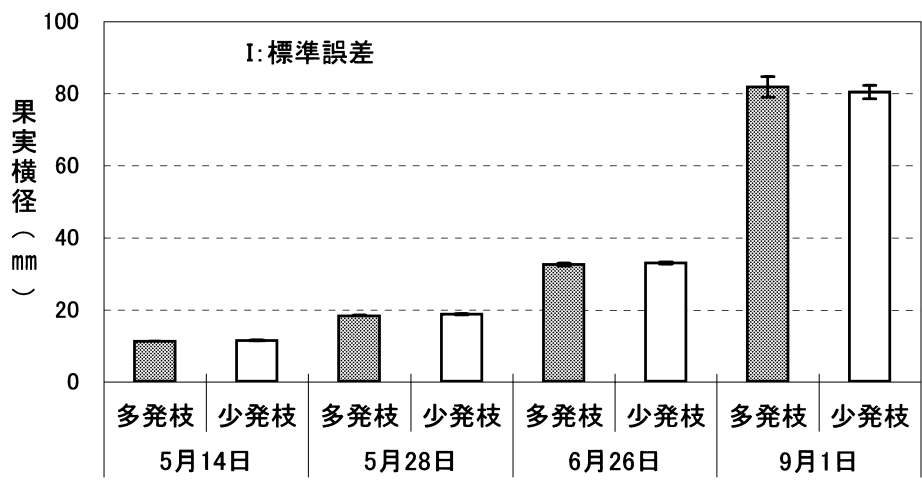

第4図＼cjkstart多発枝と少発枝における果実肥大の推移

形果率は，少発枝では $5.5 \%$ あり，多発枝では $10.6 \%$ であった(第 3 図)。

これらのことから, 本病の発生が多い場合は, 開花後 の着果率が劣り，奇形果率が高くなることが明らかにな った。

このため, 本病の発生程度が甚だしい場合には, 着果 量や果実形質に影響を及ぼすことが懸念された。そこで, A 生産団地の No. 1 園において, 慣行通りに摘果を行い, 少発枝と多発枝に残存した果実における肥大の推移を比 較した。

この結果, 果実肥大は, 本病の発生の多少による有意 な差は認められなかった（第 4 図）。

以上の結果から，本病の発病花率（園地平均）が16. 4
\%程度の被害園においては，多発枝で 1 次摘果時の落果 率や奇形果率は高まるものの, その影響は慣行の摘果作 業によりカバーされる範囲であり, 収穫期における果実 肥大には実用上の問題を生じないことが明らかになっ た。

\section{引用文献}

1）井手洋一・田代暢哉・衛藤友紀 (1998) 九州農業研究 60 : 72

2）佐藤 徽・松本省平・久原重松・後藤考雄（1973）日植病 報 $39: 143$. (講要)

3）牛山欽司（1993）神奈川園試研報 $43: 10-11$. 